\title{
Motiv posta i molitve u hrvatskoglagoljskim tekstovima 15. i 16. stoljeća
}

\author{
MARIJA-ANA DÜRRIGL* \\ • https://doi.org/10.31823/d.27.4.6 \\ UDK: 27-282.7-528“14/15“ • Izvorni znanstveni rad \\ Primljeno: 31. listopada 2018. • Prihvaćeno: 2. prosinca 2019.
}

Sažetak: Motiv posta i molitve često se zatječe u djelima raznih sadržajnih, oblikovnih $i$ vrsnih pripadnosti tijekom mnogih stoljeća, pa je moguće govoriti o motivu dugoga trajanja. U trima se glagoljskim kodeksima iz 15. i 16. stoljeća (u tzv. Oxfordskom, Berčićevu i Grškovićevu zborniku) nabrajaju osobe iz Biblije i svetci koji su postili i tako postigli spas $i$ milost. U tim je spomenicima popis likova u velikoj mjeri podudaran. Po tonu i stilu zaključuje se kako su tekstovi bili namijenjeni širem krugu primatelja, a ne (samo) užoj redovničkoj ili duhovničkoj zajednici. Tekstovi su analizirani s književnoteorijskoga polazišta, s naglaskom na njihovoj strukturu, a identificirane su dvije važne karakteristike hrvatskoglagoljske proze. To su polifunkcionalnost,

* dr. sc. Marija-Ana Dürrigl, Staroslavenski institut, Demetrova 11, 10000 Zagreb, Hrvatska, duerrigl@stin.hr jer djela često ujedinjuju praktične (npr. pastoralne, moralne $i$ poučne) funkcije s estetskom, te otvorenost forme, jer se teme, motivi i slike pojavljuju u uvijek novim kombinacijama $i$ kontekstima (specifična intertekstualnost). $U$ analiziranim se tekstovima prepoznaju figure i tropi tipični za hrvatsku srednjovjekovnu prozu (npr. antiteza, paregmenon, nabrajanja, dijade, trijade, asonancije, sintaktički i leksički paralelizam).

Ključne riječi: post i molitva kao književni motiv, srednji vijek, rano novovjekovlje, hrvatskoglagoljska književnost, Oxfordski zbornik, Berčićev zbornik, Grškovićev zbornik. 


\section{Uvod: srednjovjekovna književnost kao dio kulture pamćenja}

Jedan od čestih motiva srednjovjekovne književnosti - Ernst Robert Curtius bi možda kazao toposa ${ }^{1}$ - koji se kombiniraju stavljanjem u uvijek nove kontekste jest motiv posta i molitve (te činjenja dobrih djela), s osobitim naglaskom na to koju su posljedicu imali u životima posebnih, iznimnih ljudi. Taj je motiv poznat već u biblijskim tekstovima i često su ga tematizirali redovnici koji su u brevijarskim i misalskim čitanjima čitali ili slušali o postu i molitvama. Hrvatskoglagoljska pisana tradicija, kao dio jedne predpismene kulture, stoji na susretištu usmenoga i pisanoga, baš kao i druge europske srednjovjekovne književnosti, a to nerijetko utječe i na kompoziciju književnih sastava. U vezi s time jest i važnost liturgije, odnosno liturgijskih knjiga i njihova stila, a u njima se dijelom reflektira i stil biblijskih knjiga. ${ }^{2}$

Post i molitva motiv su duga trajanja i zatječu se u brojnim tekstovima s vjerskom tematikom, od svetopisamskih tekstova do suvremenoga doba. Ovim prilogom nastojimo pokazati kako se taj motiv pojavljuje u hrvatskim glagoljskim nabožnim tekstovima različite žanrovske pripadnosti te kako detalji poruke što ga motiv nosi djelomično mijenjaju konotaciju ovisno o nadređenom kontekstu unutar kojega se nalazi. Pokazuje se također kako se ponavljanjem istih ili sličnih toposa u primatelja pobuđuje emocionalan (ali i kognitivan) odgovor, nastojeći potaknuti primatelje na određeni način ponašanja. Varijacije okvira u koji je motiv smješten ili inkorporiran na prvi pogled ne djeluju kao znatne, ali ipak su djelomično uvjetovale razlike u nijansama ne samo značenja i poruke već i neke stilističke detalje. Trijada post, molitva, djela milosrđa označavala je trojni odnos u čovjekovu životu: odnos prema sebi (post), odnos prema drugim ljudima (dobra djela, tj. milosrđe) te naposljetku odnos prema Bogu (molitva).

Budući da je riječ o čestom elementu koji se zatječe u kršćanskim djelima, i teološkim i umjetničkim, naglasak ovoga promišljanja nije na interpretaciji ili hermeneu-

\footnotetext{
${ }^{1}$ Usp. E. R. CURTIUS, Europska književnost i latinsko srednjovjekovlje, Zagreb, 1998. Ako se npr. post i molitva sagledavaju kao topos, tada valja biti na oprezu pri analizi jer »the attempt to trace the continuance of a topos can lead to a blurring of qualitative distinctions, distinctions that may be crucial for deciding which structures or expressions truly belong togehter, and which are only loosely analogous. $\ll$ P. DRONKE, Poetic individuality in the Middle Ages: new departures in poetry 1000 - 1150, Oxford, 1986., 18.

${ }^{2}$ Usp. L. DOLEŽALOVÁ, Measuring the Measuring Rod: The Bible and Parabiblical Texts within the History of Medieval Literature, u: Interface (2017.)4, 39-58. Liturgija - ne samo misa, već i redovnički časovi - u srednjem vijeku imala je i didaktičnu funkciju, jer je kroz nju šira vjernička zajednica (listom nepismena) dobivala pouku o sadržajima vjere; kroz njih se jačao osjećaj zajedništva i poticalo se na emotivni odgovor na čuveno/viđeno. Usp. E. B. VITZ, Liturgy as Education in the Middle Ages, u: R. B. BEGLEY, J. W. KOTERSKI (ur.), Medieval Education, New York, 2005., 2034. Tomu treba dodati i da su se kroz liturgijske tekstove (biblijska čitanja, psalme, antifone i dr.) razvijali ukus i senzibilitet pastve.
} 
tici, već na kompoziciji i rekompoziciji odabranih tekstova, dakle na gradbi pisanih spomenika iz raznih razdoblja (15. i 16. stoljeće) te s raznih područja Hrvatske; među njima nisu dosad uspostavljene izravne kodikološke i tekstološke poveznice. Da bi pisac mogao stvarati, mora prije svega biti čitatelj - dakle pisari (ili pisci) ${ }^{3}$ promatranih glagoljskih kodeksa čitali su (i slušali!) razne sastave u kojima se spominju, tematiziraju, oprimjeruju i tumače post, molitva i djela milosrđa. Glagoljaški su pisci dakle uvijek najprije čitatelji, pa je njihova kreativnost na neki način derivirana jer proizlazi iz onoga što su čuli, pročitali, upamtili.

\section{Hrvatski glagoljaši i postupak (re)kompozicje motiva}

Duhovno je ishodište svih promatranih djela srednji vijek, sa svojim nazorima i specifičnom osjećajnošću. Kao i svaka predpismena kultura, i srednjovjekovna je kultura po svom karakteru bila bitno kultura pamćenja. Namjena nekih od sačuvanih hrvatskoglagoljskih zbornika kao priručnika za svećenički podmladak ${ }^{4}$ nije, strogo uzevši, više doli pretpostavka. Ostaje barem dijelom otvoreno pitanje za koga su se ti rukopisi, te zbirke sastavljale. U prilog tvrdnji o udžbenicima za svećenički pomladak govori raznorodnost nekih od rukopisa jer se u njima zatječu različiti tekstovi, od crkvene kazuistike do vizija, od sermona do svetačkih legendi, od egzempala do svjetovnih romana, od moralno-didaktičnih tekstova do Marijinih mirakula. Međutim znatna prisutnost upravo sermona i homilija govori protiv oštroga dijeljenja korpusa liturgijskih od neliturgijskih spomenika. Za sve to morali su postojati izvori iz kojih / prema kojima se prevodilo i sastavljalo.

Memorija ili pamćenje od sv. Augustina nadalje shvaćana je kao škrinja iz koje je moguće uzimati dijelove i uvijek ih sastavljati u nove cjeline. U srednjovjekovlju se prepoznaje kreativnost po načelu variranja, a ne po načelu koje bismo s današnjega gledišta nazvali individualnošću. Primjerice povjesničarka književnosti Helen Leith Spencer ističe nevoljkost engleskih pisaca propovijedi da stvaraju izvornu prozu. ${ }^{5}$ Kao razlog tomu ona ističe kako individualno, osobno i pojedinačno nije imalo trajni autoritet. Njezina se tvrdnja može primijeniti i na hrvatske srednjovjekovne pisce, a može se primijeniti i na pripovjednu prozu. Tadašnji odnos prema kreativnosti uvjetuje ono što se može nazvati fenomenom »pisanja po varijaciji « ili »derivativnoj individualnosti $<$; a taj se razabire i u hrvatskoglagoljskoj književ-

\footnotetext{
${ }^{3} \mathrm{O}$ problemu autorstva i autoriteta u srednjovjekovlju v. npr. A. MINNIS, Medieval Theory of Authorship. Scholastic Literary Attitudes in the Later Middle Ages, Philadelphia, 2010.

${ }^{4}$ Vidi E. HERCIGONJA, Povijest hrvatske književnosti 2: Srednjovjekovna književnost, Zagreb, 1975. 198-200.

5 »Writers of medieval English sermons are noticeably, and by our standards peculiarly, unwilling to write original prose « H. L. SPENCER, Middle English Sermons, u: B. M. KIENZLE (ur.), The Sermon (= Typologie des sources du Moyen Age occidental 81 - 83), Turnhout, 2000., 635.
} 
nosti. Preslagivanje motiva odraz je memorijskoga karaktera cjelokupne srednjovjekovne kulture, pa tako i hrvatskoglagoljske. Ono što se usvoji kao vlastito može se razmjerno $\gg$ slobodno kombinirati $\ll$.

O dekompoziciji i rekompoziciji u srednjovjekovnim književnim ostvarenjima mnogo je pisano, a taj se fenomen jasno razaznaje i u postupku hrvatskih popova glagoljaša. ${ }^{6}$ Srednjovjekovna je estetika duboko povezana s konceptima memoria i intentio u njihovim raznim valerima. ${ }^{7}$ To vrijedi za velebna ostvarenja arhitekture kao što su crkve i samostani, ali i za neznatnija književna djela o kojima će ovdje biti riječ. Iz razmjerno malenoga broja hrvatskoglagoljskih tekstova odabrani su oni u kojima se kao važan motiv pojavljuju post $i$ molitva. To se ne odnosi samo na određeno poželjno ponašanje, već na cjelovito osjećajno i duhovno usmjerenje čovjeka.

Prepisivanje tekstova, poznato je, bilo je dijelom svećeničke/redovničke svakodnevnice i valjalo je poštovati tekstni predložak. No ipak se vidi kako je riječ češće o prilagodbama, makar samo u sitnim jezičnim detaljima (npr. crkvenoslavenski prema živim govornim morfološkim oblicima itd.). Sačuvani rukopisni materijal pokazuje kako su srednjovjekovna djela bila stalno na neki način obnavljana, što ne valja dovoditi u vezu isključivo s postupkom prepisivanja, nego je ta pojava vezana uz postupak dekompozicije. Taj je pak ovisan o spomenutom pamćenjskom značaju srednjovjekovne književnosti i o »situacijskoj《 vezanosti tih djela, jer su bila oblikovana s pogledom na primatelje; riječ je o načelu pisanja naglas. ${ }^{8}$ Općenito se može reći da se u antici i srednjem vijeku prakticiralo čitanje naglas, čitalo se usnama i ušima, a ne samo očima. Stoga legere uključuje i audire, jer je riječ o akustičnom čitanju u kojem se događa dijalog: slušanje je po sebi dijaloško zbivanje. Ono se moglo odnositi na prepisivanje teksta iz starijih knjiga ili pak na čitanje tekstova onima koji ne umiju čitati ili nemaju knjiga. Takvo je čitanje dakako imalo izraženiji karakter komunalnoga, zajedničkoga i izravnoga, što je njegova važna značajka. ${ }^{9}$

\footnotetext{
${ }^{6}$ M.-A. DÜRRIGL, O čitanju, pisanju i kompiliranju u hrvatskoglagoljskom srednjovjekovlju, u: Slovo (2010.)60, 219-234.

${ }^{7}$ Usp. M. CARRUTHERS, The Craft of Thought: Meditation, Rhetoric, and the Making of Images 400 - 1200, Cambridge, 1998., M. CARRUTHERS, J. ZIOLKOWSKI (ur.) The Medieval Craft of Memory: An Anthology of Texts and Pictures, Philadelphia 2002., M. CARRUTHERS, The Experience of Beauty in the Middle Ages, Oxford, 2013., s iscrpnim bibliografijama.

8 » Writing aloud «, kako to u naslovu svoje knjige formulira N. M. BRADBURY, Writing Aloud: Storytelling in Late Medieval England, Chicago 1998.

${ }^{9} \gg$... Erbauliche Funktion der Literatur ist nicht individualisierende, sondern Gemeinde zusammenführende Funktion, was nicht nur die literarische Produktion bestimmt, sondern auch die Rezeption, etwa das gemeinschaftliche Hören während der klösterlichen Mahlzeiten, im Gegensatz zur späteren Sitte ausschließlich individuellen Lesens.« K.-D. SEEMANN, Thesen zum mittelalterlichen Literaturtypus und zur Gattungssystematik in der altrussischen Literatur, u: W.-H. SCHMIDT (ur.), Gattungsprobleme der älteren slavischen Literaturen, Berlin - Wiesbaden, 1984., 283.
} 
Pritom tekstovi u svojoj retorički organiziranoj strukturi imaju određene rukohvate (a to su prepoznatljiva opća mjesta, metafore, slike, simboli i dr.) što služe poput pomagala koja će spriječiti lutanje primateljevih misli, koja će dakle spriječiti curiositas (tj. grješno i nezdravo lutanje misli).

Za ovo promišljanje uloge i važnosti pamćenja i sjećanja u procesu oblikovanja novih sadržaja polaznica može biti i formulacija koju u svojem vizionarskom djelu Liber vitae meritorum rabi Hildegarda iz Bingena: in memoriam bonę scientię componat. ${ }^{10} \mathrm{Tu}$ se povezuju memoria (kao pamćenje i sjećanje; kao škrinja pohranjenih sadržaja, ali i kao djelatnost, aktivnost) i komponiranje. Shvatimo to kao slaganje tekstnih odlomaka ili raznih tema/sadržaja, jer Hildegarda nije upotrijebila izraz deriviran od creatio. Glagol componere odnosi se na slaganje, organiziranje, sređivanje. A ono što među njima tvori most jest bona scientia, dobro znanje ili pak znanje o dobrome. Onaj tko razumije tekst »slaže ga u pamćenju dobroga znanja « pa ga učitava u svoje ponašanje i život. Ispravan je život, po Hildegardi, pravilno iščitavanje i interpretacija Božjih zakona i čovjekove uloge u povijesti. ${ }^{11}$ Tako shvaćene, na tragu srednjovjekovnih kršćanskih mislilaca, retorika i memorija imaju, u odnosu na antičko i na današnje poimanje tih pojmova, uzvišeniji karakter, cilj i ulogu jer pomažu na putu ljudskoga uzdizanja prema eshatonu.

Tipična otvorenost forme srednjovjekovnih tekstova, pa tako i hrvatskih, ne može se dakle svesti samo na prepisivanje s različitih predložaka (ili prevođenje s njih); ona je bila uvjetovana fundamentalnim memorijalnim/memorijskim značajem srednjovjekovne kulture - ono što se usvoji kao vlastito može se »slobodno kombinirati «. Tekstni izvornik jest autoritet, a plagijat i originalnost pojmovi su moderne umjetničke književne produkcije koji se na srednji vijek ne mogu u potpunosti primjenjivati. Za srednjovjekovne se tekstove može tvrditi da ne funkcioniraju kao strogo zatvoreni i završeni sustavi, već su u pravilu prožeti citatima, parafrazama,

${ }^{10}$ Usp. kritičko izdanje Hildegardis Bingensis Liber vite meritorum, u: A. CARLEVARIS (ur.), Corpus Christianorum Continuatio Mediaevalis, XC, Turnhout, 1995., 65.

${ }^{11}$ Sličnost se može prepoznati s uputom ili pozivom autorskoga pripovjedača (glagoljaša prevoditelja) publici koja je slušala $\gg$ Dundulovu/Tundalovu viziju $\ll u$ tzv. Petrisovu zborniku iz 1468. g.: $o$ prevz'lûbleni Bogom krst'êne ovo govoren'e ko ste slišali da e imeite vazda na vašoi dobroi pameti [... ] gus'to pročitaûce ove knige. Slušanje i čitanje tu se spajaju, a poruku je valjalo stalno imati na dobroj pameti - bona scientia Hildegarde iz Bingena. Glagoljski se tekstovi donose u latiničnoj transliteraciji prema načelima za izradu Rječnika crkvenoslavenskoga jezika hrvatske redakcije (što se priprema i izdaje u Staroslavenskom institutu u Zagrebu): glagoljsko slovo jat donosi se kao ê, slovo đerv kao $\hat{\jmath}$, slovo šta kao $\hat{c}$, a jus kao û. Kratice su razriješene u okruglim zagradama, a u većem je dijelu navoda ostavljena izvorna interpunkcija i pisanje velikih odnosno malih slova (npr. u imenima ili izrazima kao gospod, bog ili pak Isus). 
uputnicama i poveznicama s drugim djelima. ${ }^{12}$ Srednjovjekovni autori (a u njih se mogu ubrojiti i prevoditelji i prerađivači) svoja su djela redovito stvarali i oblikovali imajući pred sobom / na umu publiku, primatelja određenoga djela ili teksta. Dakako, nije uvijek moguće odvojiti neku konkretnu publiku od kategorije implicitnoga primatelja, prije svega zbog toga što je najčešće riječ o javnome čitanju naglas, pred većim brojem ljudi (a ne o zasebnom, tihom čitanju u sebi). Na taj način dolazi se do izvedbe, a u njoj su primatelji svojevrsna unutartekstovna kategorija - otuda i važna žanrovska odrednica adresat. Mouvance (termin Paula Zumthora), odnosno mogućnost da se dijelovi srednjovjekovnih tekstova slažu i preslažu u raznim nadređenim kontekstima, tj. unutar različitih cjelina koje sagledavamo kao odijeljena djela, zamjećuje se u nizu sačuvanih hrvatskoglagoljskih ostvaraja. Taj je fenomen i posljedica, ali i uzrok otvorenosti forme srednjovjekovnih tekstova, koje je onda posljedično - teško i nezahvalno kategorizirati s obzirom na žanr ili vrstu. Riječ je o grozdovima motiva koji se prepoznaju u raznim tekstovima zapisanima u raznim zbornicima, kroz nekoliko stoljeća i na većem zemljopisnom prostoru. Opća su to mjesta kršćanske moralke, a autori i pisari umeću ih u manje ili više različite (ako hoćemo, manje ili više slične) kontekste, a da pritom imaju sličnu namjeru: pokazati korisnost i duhovnu dobrobit nekoga oblika ponašanja ili održavanja neke tradicije.

\section{Post, molitva (i dobra djela): čest motiv i uzor za ispravan život}

Dopustit ćemo si poveznicu s omiljenom srednjovjekovnom metaforom o autoru kao graditelju: Post i molitva jedan je od često korištenih gradbenih blokova ili motiva u hrvatskoglagoljskim zbornicima koji ne mijenja bít poruke (valja postiti, moliti i činiti dobro potrebitima), malo se mijenja sadržajno (tko je u povijesti molio i postio te što je dobra takvo ponašanje donijelo), a kad se uklopi u različit kontekst, dobiva ponešto novu fasadu, ali temelj ostaje isti: to se čini za dobrobit duše i tijela, za pojedinca i za zajednicu. Plodovi će biti mnogostruki; za malo odricanja dobit će se velika nagrada! Povjesničarka Caroline Walker Bynum pokazala je kako su u srednjem vijeku pričest i post bili središnje točke vezane uz promišljanje hrane i hranjenja, i u duhovnom i u tjelesnom smislu. ${ }^{13}$

Upravo je takav primjer motiv posta i molitve u trima hrvatskoglagoljskim sastavima. Riječ je o prenju Isusa s đavlom ${ }^{14}$ kao dijelu propovjednoga teksta u tzv. Oxford-

\footnotetext{
${ }^{12}$ Usp. M. WORTON, J. STILL, Intertextuality: Theories and Practices, Manchester, 1990., 2.

${ }^{13}$ Usp. C. W. BYNUM, Holy Feast and Holy Fast: The Religious Significance of Food to Medieval Women, Berkeley, 1988., 31. i nadalje upozorava na opće mjesto odnosa prema patnji uzrokovanoj odricanjem, a koje se često pojavljuje i u našim spomenicima: »suffering meant redemption «. Isto, 250.

${ }^{14}$ Sve je glagoljske inačice teksta u latiničnoj transliteraciji objavio S. SAMBUNJAK, Jezik i stil hrvatskih glagoljskih prenja, Split, 2000., 227-237.
} 
skom zborniku iz 15 . stoljeća (dalje u tekstu: COxf), ${ }^{15}$ o postu i molitvi u okviru poučno-dijaloškoga teksta u tzv. Berčićevu zborniku iz 15. st. (dalje u tekstu: CBč) ${ }^{16}$ te o moći koju imaju molitva i post u okviru moralističkoga teksta o potrebi pokajanja zbog učinjenih grijeha u tzv. Grškovićevu zborniku iz 16. st. (dalje u tekstu: CGrš $).{ }^{17}$

Ako su im svima namjera i svrha bile iste - poticaj na jednu vrstu ponašanja, a odvraćanje od neprihvatljivoga i nepoželjnoga - ipak su ductus, pa čak dijelom i via bili barem djelomično različiti. A nadređeni kontekst djela u koje su uklopljeni jest raznolik: ili moralnopoučni tekst (CGrš), ili prenje i propovijed (COxf), ili pak legendarni tekst (CBč). Dakle i vrsta teksta (žanr) i namjena teksta bili su različiti, ali poruka slična. Po tonu i stilu tekstova smije se zaključiti kako su bili namijenjeni širem krugu primatelja, a ne (samo) užoj redovničkoj ili duhovničkoj zajednici.

\subsection{Post I MOLITVA U PROPOVIJEDI UZ PRENJE ISUSA S ĐAVLOM}

Prenje Isusa s đavlom apokrifni je sastav koji je u hrvatsku književnost ušao iz zajedničke crkvenoslavenske matice, a koja je nastala prema grčkom (bizantskom) predlošku. Cjeloviti se tekst čuva u četirima rukopisnim zbornicima duhovnoga sadržaja: u tzv. Akademijinu zborniku s kraja 15. st., ${ }^{18} \mathrm{u}$ Zborniku iz Berčićeve zbirke br. 5 iz 15. st., u Oxfordskom zborniku iz 15. st. te u Žgombićevu zborniku s početka 16. st. ${ }^{19}$ Riječ je o sukobu Isusa s đavlom koji se, prema tom apokrifu, događa nakon napastovanja u pustinji (Mt 4, 1-11), a u kojem đavao iznova iskušava Isusa. Međutim i taj put Isus izlazi kao pobjednik, dapače, tjera đavla u paklene propasti, a Isus odlazi $s$ učenicima naučavati $u$ Jeruzalem. Na taj je dramatičan dijalog $u$ COxf-u dodan nešto opsežniji tekst pisan stilom i(li) glasom propovjednika koji se izravno obraća zamišljenoj publici (brat'ê), a on glasi:

${ }^{15}$ Oxford, Bodleian Library, sign. Ms. Canon. Lit. 414; to je zbornik različitoga štiva u kojem su zapisani i legendarni tekstovi, prenja, eshatološke vizije i dr. - rukopis je opisao M. TADIN, Glagolitic Manuscripts in the Bodleian Library, Oxford, u: Oxford Slavonic Papers 5(1954.), 133-144.

${ }^{16}$ Sanktpeterburg, GPB, sign. Bč5; to je zbornik pretežno duhovnoga sadržaja, s legendama, apokrifima, prenjima i sličnim sastavima - rukopis je opisala i izdala S. O. VIALOVA, Glagoljski zbornik XV. st. Ruska nacionalna biblioteka, Zbirka Ivana Berčića, f. 67, Berč. br. 5, Zadar, 2016.

${ }^{17}$ Zagreb, Arhiv HAZU, sign. VII 32; rukopis je opisao V. ŠTEFANIĆ, Glagoljski rukopisi JAZU, II, Zagreb, 1970., 45-52.

${ }^{18}$ Čuva se u Zagrebu, Arhiv HAZU, sign. IV a 48.

${ }^{19}$ Potonji se zbornik čuva u Zagrebu, Arhiv HAZU, sign. VII 30. Razlike među tim inačicama nisu fundamentalne, ali otvaraju mogućnost zapisivanja upamćenoga teksta, bez zagledanja u neki pisani predložak. Tu je moguća tek pretpostavka jer jasnih signala o tome u našim spomenicima nema. Ponekada nije moguće utvrditi prepisuje li se tekst ili se piše po sjećanju, pa se valja čuvati generalizacija. 
(50 v) ne čudite se brat'ê da g(ospod)b d'êvlu is'kusiti se poda i pri se š nim' da to bi da mir' v'zdvignu se i s'nide na križ nas' cič' i snidê v' ad' $n(a) s^{\prime}$ ciĉ.'. V pos'te i v' $m(o) l(i)$ tvah' prebivaite da budete pričes'tnici s(ve)tim' izbranim' b(o)žim' ki postom' i m(o)l(i) tvami premogoše sa mir'. G(ospod) bsp(a)sb h(rbst)b posti .k. dni i .k. noĉi ${ }^{20}$ i potom' is'kušen' bi ot d'êvla i pru imi š nim'. Post' i m(o)l(i)t(a) v' učini moiseê govoriti z'b(ogo) mb na gori sinaiscêi govori pos'tiv' .k. dni Post.k.dni i m(o)lit(a) v' ot sodomlan' i gomora sp(a) se pr(a)v(a)dnago luta. Post' i m(o)l(it)va avrama sp(a)se // (51 r) ot parauna. Post' i m(o)l(it)va sp(a)se noê v' kovčezi. Post'. k.dni i m(o)l(it)va sp(a) se isaka ot ruki avrama otca ego. Post'. k.dni i $m(o) l($ it)va osipa is tamnice eûpat'aiskie izvede. Post' $i$ $m(o) l($ it $)$ va daniela v' rovi lavovi sp(a)se. Post'. $k$.dni i $m(o) l($ it $)$ va susannu ot nevin'ne smr'ti izbavi. Post' i m(o)l(it)va iliû v'kolesnici vzdviže n(a) n(e)bo. Post'. k.dni i m(o) l(it)va êkimu i an'ni plod' da b(laženu) mariû b(ogo)r(odi)cu. Post' .k.dni i m(o)l(it)va $d(a v i) d a$ ot goliêda i saula i ot vsêh' protivnik' izbavi. Post' .k.dni i mol(it)va ot osueniê isa nav'jiina ni s'plenue amaleka pobêdi. Post'. k.dni i m(o)l(it)va iv(a)na ap (usto)la $i z ' b(a) v i$ ot patom'skoga otoka. Post' .k.dni i m(o)l(it)va teklu d( $\hat{e}) v u$ ot og'na v' ki vržena biše izb(a)vi. Postom' i m(o)l(it)vami s(ve)ta margarita cêla bi i ot utrobê z'mieve izide. Postom' i m(o)l(it)voû trih' otrokb ot peĉi ogan'ne iz'b(a)vi. Postom' i m(o)l(it) voû elizabêtu $k$ s(ve)tih' čislu pridruži. Mnozi s(ve)ti otci i m'nisi i eremiti živuĉe v' pustinah' postom' i m(o)l(it)vami vnidoše v $n(e) b(e)$ sa dobro zaisto is(ve) to e(stb) post' čist' i m(o)l(it)vu čistu prinositi $b(\mathrm{og})$ u i podanie al'mužnoga s' lûbav'û i s veru čistu $i$ s'mêrenu. I ki ovo čine poidut'v rai.

U zbijenom se nizu navode tjelesne opasnosti iz kojih post i molitva spašavaju vjerne izabrane (npr. Lota od sudbine Sodome i Gomore, Izaka od žrtvene smrti, Danijela od lavova, Suzanu od lažnih optužbi, sv. Margaretu od zmaja, a sv. Teklu od ognja) ili im daju duhovnu snagu i posebnu milost (Mojsije je smio govoriti s Bogom na brdu Sinaj, Ana i Joakim dobili su dijete, Bogorodicu Mariju, sv. Elizabeta našla je snagu za pomoć potrebitima itd.). Uza sva odricanja treba se posvetiti i bližnjima dobrim djelima i davanjem al'mužnoga, tj. milodara. Na kraju se zaključuje da će oni koji tako čine postići rajsko blaženstvo. Konac pak toga propovjednoga sadržaja u Žgombićevu zborniku kraći je, a sličan kraju u Akademijinu zborniku: ne čudite se bratiê moê draga da g(ospo(d(i)n naš Is(u)h(rbstb) dêvlu iskusiti se poda $i$ pregovara se š nim na to bo pride $v$ svet da udi svoimi nas od d'êvla izbaviti rači tako i vi bratiê prebivate $v$ poste i $v$ molitve i $v$ čistote i v lubave i va almuštve da budete pridružnici s(ve)tim' izibranim Božjim da po teh deleh i mi premožemo dêvla i od Boga večni $z$ zivot primemo $v$ ko nas privedi otac $i$ sin $i$ duh sveti amen.

U trima se inačicama dakle prepoznaje prijelaz iz izravnoga obraćanja (ne čudite se bratiê moê draga) nekoga tko pripovijeda/propovijeda u prvo lice jednine, dakle

\footnotetext{
${ }^{20}$ U glagoljskoj azbuci slovo K ima brojnu vrijednost 40.
} 
stvara se zajedničko, molitveno mi kršćanske zajednice ( $i$ mi premožemo dêvla) koje je potrebito Božje naklonosti i koje treba činiti dobro. Post navedenih osoba jest imitandum, nešto što valja nasljedovati, a ispravan kršćanski život donijet će nagradu u vječnosti. $U$ tom smislu nema zastrašivanja paklenim mukama ili kaznama za grijehe, a koje je inače često u srednjovjekovnim tekstovima eshatološke tematike. Uz biblijske osobe spominju se tri svetice (!) kojima su post i molitva pomogli na putu uzdizanja do Boga: dvjema su tako spašeni životi (sv. Tekla spašena je s lomače, a sv. Margareta iz utrobe zmaja), dok je sv. Elizabeta prepoznatljiva upravo po svom asketskom životu i dobrim djelima prema potrebitima.

\subsection{BERČIĆEV ZBORNIK - LEGENDA I PRENJE}

U Berčićevu zborniku (CBč) zapisan je moralnopoučni i pobudbeni tekst o pokajanju na str. $2 \mathrm{r}-4 \mathrm{r}$ u kojem se također zatječe motiv posta i molitve. Spomenuti je tekst po kompoziciji svojevrstan compositum ${ }^{21}$ ne samo žanrova nego i tema jer se od pouke o korisnosti posta i molitve prelazi u prijepor sv. Margarite s đavlom. To je po vrsnoj pripadnosti »malo prenje « koje se tako može nazvati analogijom prema Dinzelbacherovu pojmu $\gg$ mala vizija $\ll .{ }^{22}$ Naime riječ je o epizodi disputacije, prepirke u nadređenom legendarnom tekstu. Malim se prenjem dramatizira tekst i pojačava dojam na primatelja. Umjesto da pokuša progutati sveticu, đavao s njom ulazi u prijepor, a na kraju priznaje pobjedu pobožnih i poniznih vjernika. Na taj način, baš kroz usta đavla (gotovo oksimoronski), moralna pouka postaje još snažnijom. Tako poruka/pouka na primatelja ima još jači učinak, a đavao od čovjekova protivnika postaje pomoćnikom, barem načas, time što kaže: $k i$ se obratet' na postb i na $m(o) l(i)$ tvu $B(\mathrm{og})$ a radi To ti ne poidut' sa mnu na osuenie vếño. $\mathrm{U}$ tom se segmentu prepoznaje i daleka paralela s prenjem Slovo meštra Polikarpa, gdje personificirana Smrt poučava čovjeka o umijeću neporočnoga života i dobre smrti, pa mu također postaje ne samo aktantski već i ontološki pomoćnik. ${ }^{23}$ Svetica se u navedenom odlomku iz COxf-a samo spominje, dok je ovdje djelatnija kao lik, jer se ne plaši ući u izravan dijalog $\mathrm{s}$ đavlom/zmajem. Osobitost prijepora jest u tome što strašni zavodnik svijeta đavao, najgori čovjekov protivnik na ontološkoj razini, iskazuje pohvalu (via negationis!) postu, molitvi, dobrim djelima - upravo krjeposnom životu.

${ }^{21}$ Izraz posuđen iz srednjovjekovne farmacije.

${ }^{22}$ M.-A. DÜRRIGL, Neki aspekti genologije prenja u hrvatskoglagoljskoj književnosti - o naslovnim pojmovima i malim prenjima, u: Croatica (Hercigonjin zbornik) 26(1996.)42-43-44, 89-95.

${ }^{23}$ Usp. M.-A. DÜRRIGL, Mors magistra vitae - jedno čitanje Slova meštra Polikarpa, u: Slovo (2004.)52-53, 41-54. Takav je pomak moguć u srednjovjekovnim vjerskim djelima u kojima uvijek uz estetsku vrlo izraženu ulogu imaju i praktične funkcije (prije svega pastoralna i moralna). 
U okviru cjeline navode se i dokazi korisnosti molitve i posta ne samo za postizanje duhovne vrline nego i za intelekt, za učenost, što je rijedak primjer u našim zbornicima. Nadalje odabrani odlomci teksta vezani uz post i molitvu u CBč-u glase:

(2r) Postb m(o)l(i) tva i maše s(ve) te Iliû pr(oro)ka vznese n' n(e)bo Postoms i m(o) litvoû ap (usto)li g(ospodb)ni braniše se i odolêse c(êsa)r(e)mb idol'skimb [...] Post' $i$ $m(o) l(i t)$ va $i z b(a)$ vi.v. (=3) otroki ot peĉi og'na

(3r) Postom' i m(o)litvoû b(la)ž(e)nomu Mikuli oblast' bê dana od' B(og)a v's(a) komu $\check{c}($ lovê)ku pomoĉi [...] Postb i m(o)l(i)tva s(veta)go Grg(u)ra bê emu pomoĉb na razums k'nižni [...] Post' i $m(o) l(i)$ tva priêtb b(la) ž(e)nago Benedik'ta Ozida grado protivu d'êv'lu [...] Postoms i m(o)l(i)tvami žena grišnnica priêta bê ka sl'zami umi nozi G(ospodb)ni [...] I bê očicenena ot' gr(ê)hovb Postom' i m(o)l(it)vi ee s(ve)te Mar'garite bê oružna protivu d'êv'lu [...]

(4r) ir (eče) ei d'êv(a)lo ki se obratet' na postb i na m(o)l(i)tvu B(og)a r(a)di To ti ne poidut's sa mnu na osuenie vêčno

Na kraju se autorski pripovjedač manirom propovjednika obraća primateljima: Poslušaite $b(r a) t(i) \hat{e} k(a k o)$ d'êv (a)lo hv(a)litb poćenie i $m(o) l(i)$ tvu. Zato obratimo se na dobra dela da nasb $B(\circ g)_{b} p(o) m(i) l u e v^{\prime} v(\hat{e}) k i v(\hat{e}) k b a m(e) n b$.

Popis biblijskih likova koji poste ovdje je značajno kraći, samo prorok Ilija ${ }^{24}$, apostoli i tri mladića u ognjenoj peći. Spominje se i anonimna grješnica koja se obratila i okajala grijehe. Osobito se ističe kako je Mikula pomoću posta i molitava razvio vrlinu da pomaže potrebitima, Grgur je tako lakše otvorio svoj duh za naobrazbu i teološko znanje (koje prenosi i drugima i jedan je od najčitanijih teoloških autora u srednjem vijeku), a Benedikt je samoprijegorom i postojanim molitvama dobio nadahnuće za oblikovanje načina života, za samostansku regulu - to su tri primjera što se sve može postići postom i molitvom. Razaznaje se sličnost s postupkom u COxf-u gdje se spominju tri svetice; svaki se put navode tri značajne osobe koje su uzdržavanjem i pouzdanjem u Boga ostvarile svetost, iznimnost i blagoslov. U tekstu se prepoznaju figure i tropi tipični za našu srednjovjekovnu prozu (npr. antiteza, paregmenon, nabrajanja, dijade, trijade, asonancije, sintaktički i leksički paralelizam).

\subsection{GRŠKOVIĆEV ZBORNIK - POST I MOLITVA NA POČETKU MORALNOPOUČNOGA SASTAVA O POKAJANJU}

U cjelini dužega moralnopoučnoga sastava, dakle teksta bez narativnih značajki, pod naslovom Ot pokaênie grihov' u CGrš-u od fol. 126 verso do fol. 127 recto spo-

\footnotetext{
${ }^{24}$ Ilijino je uznesenje postignuto i uz pomoć maše svete, što je svojevrstan anakronizam, koji je međutim funkcionalan u cjelini teksta i njegove poruke.
} 
minju se i dobrobiti posta i molitve, a vrlo je važno zamijetiti da pisar na margini zapisuje nešto poput upozorenja, a ono može funkcionirati i kao naslov, ali i kao izravno obraćanje čitatelju, čime konativna funkcija postaje izrazitija: čti $k u$ moĉ' ima post i molitav'. Važno je naglasiti kako su primjeri posta i molitve zapisani upravo na početku opsežnijega sastava o pokajanju - time su oni začetak, stasis za obraćenje i dobar život! Od ranoga srednjega vijeka do njegova sutona u raznim se teološkim traktatima ponavljalo kako biti kršćanin znači moliti, biti pripravan primiti Boga u svoje raskajano i zahvalno srce. Molitva naime otvara srca, rasvjetljuje razbor, sapere grijehe s duše i potiče čovjeka na ljubav prema svomu Stvoritelju. Ona je i snažno oružje kojim se mogu sačuvati od iskušenja i grijeha. ${ }^{25}$

Tekst se otvara slobodnim parafraziranjem evanđeoskih i novozavjetnih mjesta koja govore o molitvi, a glasi ovako:

\section{6 v Ot pokaêniê grihov' ćti razumno}

Podvignimo se bratiê da ne tegnemo v mirilih' naših' zlobu našu ere ako zloba naša ako imala e(sto) ona veliku tegotu ima $v$ sebi togo radi ${ }^{26}$ dobra dela tvorimo moleĉe se $G(o s p o) d(i) n u$ Bogu G(ospodb) govorit' moleĉim se. Vele ne govorite kako ezični ipokriti. Ovo est' potribno u Boga prositi knežiê Ili vladanê ili bogatastva to vse prose neverni pa vi bratiê prosite cesarstva bož(i)êe Vist bo ot(a)c' vaš' nebeski kako prosite sih' vsih' da podvignimo se bratiê dobra dela tvoriti pokaêniem' sa slzami. Post' i molitva Iliû proroka uznese na kolesnice na nebo ognenê. Post' i molitav' nareče goniti dêvla Iliû. Post' i molitav' provede Moisiê skozi more črmnoe sa sinmi iz(drai)levimi. Post' i molitav' izvede Lota ot' Sodoma i Gomora ka se podvratista. Post' i molitav' Moisiû hrabr biše kada kada na svetoi gori molaše se Gospodinu Bogu a Êrun' ravaše se s pogani. Post' $i$ molitav' izbavi Daniela ot rova lavova. Postom' i molitvu David cesar vzraste // (127 r) is propasti zemalnie. I paki ga post' i molitva va višni Erusolim' vavede i učini ga biti načelnika peniû pravadnim'. Post' i molitva Pavla ap (usto)la stvori pohoditi vse muke i vidi žitak' pravadnih'. Post' i molitva bi na preprenie dêvlu kada $H(r s t b)$ posti se .k. dnni i .k. noĉi. Postom' i molotvồ [sic!] odoliše ap (usto)li cesarom' idolskim' i obratiše $p l(b) k^{\prime} v$ službu Božiû. Post' i molitav' biše moĉ́ mučenikom' i kripost' Post' i molitva izbavi tri otroki ot peĉi oganne. Post' i molitav' dobro oružie i kripko e(stb) protivu dêvlu vobitelu (vabitelu??) dušam' našim' I vsaki čl(ovê)k' ki čini dêvla dela oblastan' e(stb) dêvlu živiti v nem'.

Takav početak teksta djeluje poput sjemena iz kojega niče pouka cjeline. Nizom potvrda iz posvećene povijesti ostvareno je i ovdje nabrajanje primjera o korisnosti

\footnotetext{
${ }^{25}$ Usp. R. FULTON BROWN, Oratio/prayer, u: P. Z. BECKHAM, A. HOLLYWOOD (ur.), The Cambridge Companion to Christian Mysticism, Cambridge, 2012., 167-177.

${ }^{26}$ Nejasno mjesto u tekstu.
} 
posta i molitve u postizanju dobra, a zapravo još više u izbjegavanju zla. Stoga se pretpostavljena publika (vjernička pastva) poziva da posti i moli te da čini djela milosrđa. Ali ne smije se moliti za bogatstva i slavu, jer tako čine ipokriti, već treba moliti Božji oprost i pomoć u životu. Pa i kralj David, koji bijaše pokleknuo pred izazovom tjelesnosti, pokajao se, postio i molio te tako ponovno zadobio Božju milost. Dapače, napisao je psaltir (tako se barem naslućuje iz pomalo nespretnoga izraza pisara: biti načelnika peniû pravadnim'). Tu je i referencija na biblijsku scenu u kojoj je Isus pobijedio davla (bi na preprenie dêvlu). Od podrobnosti te inačice možda je zanimljivo primijetiti da uz kanonske biblijske osobe i događaje - premda o njihovu postu Biblija ne mora ništa reći - autor povezuje apostola Pavla s apokrifnim viđenjem onostranosti, dakle poziva se na autoritet apokrifa. Primatelje se poziva na obraćenje sa slzami, s mnogo osjećaja i vanjskih znakova žalosti. U srednjem su se vijeku, barem kako nam je razaznati iz pisanih izvora, osjećaji javno iskazivali i pokazivali. ${ }^{27}$ Cijeli je tekst poticajan, upućuje na potrebu kajanja i obraćenja, a primjeri iz Svetoga pisma djeluju poput kakvih $\gg$ malih putokaza $\ll$, poput mikroegzempala. ${ }^{28} \mathrm{O}$ njima se dosta i znalo, o njima se moglo i razglabati, jer ono što nije doslovce zapisano moglo je kazivaču biti poticaj da ispriča neku priču u izravnom obraćanju primateljima. Svi su ti primjeri bili svojevrstan putokaz za obraćenje i očišćenje od grijeha te za ispravan kršćanski život. To je jasno iskazano: post' i molitav' biše moć 'mučenikom' i kripost'. Iznimne osobe kao uzori kadšto su imagines, slike i zrcala za unutarnje oči publike jer potiču na određenu vrstu stava, ponašanja i postupaka. Time spomenute - i iz toga svima očito dobro poznatoga biblijskoga ili legendarnoga konteksta izljuštene - osobe/likovi ilustriraju, upravo potvrđuju učinkovitost odricanja. S druge strane, kao suprotnost, na kraju se upozorava kako oni koji se ne ponašaju prema evanđeoskim načelima, koji ne čine dobra djela i ne mole, slijede put đavla i ne će dobro završiti: I vsaki čl(ovê) k> ki čini dêvla dela oblastan $>e(s t b)$ dêvlu živiti v nem>. U njemu dakle živi sam đavao i posljedično ga vuče $\mathrm{u}$ vječnu propast.

Usporedi li se tekst u starijem Oxfordskom zborniku s mlađim u Grškovićevu zborniku, raspoznaje se da se imena osoba u velikoj mjeri podudaraju, ali se kadšto uz njih vezuje nešto drugo u čemu su im post i molitva pomogli. Kralj David primjerice u dvama se tekstovima spominje u raznim situacijama: u COxf-u post ga spašava

\footnotetext{
${ }^{27}$ Usp. priloge u A. KAPETANOVIĆ (ur.), Poj željno! Iskazivanje i poimanje emocija u hrvatskoj pisanoj kulturi srednjega i ranoga novog vijeka, Zagreb, 2012.

${ }^{28}$ Detalj o Mojsiju koji je hrabar na gori vezan je očito uz čitanje brevijara i moljenje časova, jer se primjerice u tzv. Drugom beramskom brevijaru iz 15. stoljeća čita Moisêi $r(a) b b$ b(o)ži posti se .k. $d(b) n v$ $i$ k.k. noĉi da zakon g(ospoda)no utegal' bi priêti, dakle da je postio kako bi uopće smio primiti Božje zapovijedi. To je tek jedan od golemoga broja primjera utjecaja liturgijskih knjiga na neliturgijske zbornike, kakva su ovdje promatrana tri hrvatskoglagoljska rukopisa.
} 
od Golijata, a u CGrš-u vraća ga u okrilje Božje dobrote nakon što je bio sagriješio. Drugi su pak likovi i njihove situacije isti, s tim da je zanimljivo kako i u COxf-u i u CGrš-u, baš kao i u CBč-u, tri otroka, tj. tri mladića dolaze na kraju popisa, premda bi ih se očekivalo na početku jer su starozavjetni likovi. Formulacija o apostolima gotovo je identična u CBč-u (Postoms i $m$ (o)litvoû ap(usto)li g(ospodb)ni braniše se i odolêše c(êsa)r(e)mb idol'skimb) i u CGrš-u (Postom' i molotvoû [sic!] odoliše ap (usto)li cesarom' idolskim' i obratiše pl(b)k'v službu Božîu). Može se reći da proučavani tekstovi (koje dijeli i vrijeme, ali i mjesto nastanka/zapisivanja) - iz relativno ograničena korpusa kakav je sačuvani hrvatskoglagoljski - ilustriraju varietas, tj. postupak u kojem autor/pisar uzima poznati motiv, ali ga stavlja u novi kontekst, krati ga ili dulji i tako mu daje i neke nove karakteristike. U pisanju se prepoznaje formulaičnost i nastojanje oko skladnoga ritma. Repeticije i paralelizmi postižu i učinak kao kod recitiranja litanija (ili moljenja naglas), ali i učinak usmjeravanja primateljeve pozornosti na ono što slijedi. Pisar COxf-a rabi više varijacija jer se formulacija post' i molitav'/molitva javlja 5 puta, post .k.dni i molitva/molitav' javlja se 8 puta, a sintagma postom' i molitvami/molitvồ 4 puta. Slično tomu u CGrš-u post' $i$ molitva/molitav' spominju se 9 puta, a postom' $i$ molitvu 3 puta. Međutim temeljni je oblik gotovo identičan: post i molitva, ime osobe, situacija (blagoslov: napast, opasnost). Post' i molitav' izbavi Daniela ot rova lavova (CGrš), Post' i m(o) $l(i t)$ va izb(a)vi .v. (=3) otroki ot peĉi og'na (CBč), Post'.k.dni i m(o)l(it)va susannu ot nevin'ne smr'ti izbavi (COxf), Postomb i m(o)l(i)tvami žena grišnnica priêta bê ka sl'zami umi nozi G(ospodb)ni i bê očiĉena ot' gr(ê) hovb (CBč).

U CGrš-u se izrijekom spominje »moć« koju post i molitva daju ljudima/vjernicima u raznim situacijama, pa je i tu ozračje pozitivno, a ne zastrašujuće. Isto tako govore i odlomci u COxf-u i CBč-u, jer u svim trima promatranim zbornicima prevladava nada, poput uskrsnoga raspoloženja: kao što je Isus pobijedio đavla, a on će biti konačno uništen pri Kristovu drugom dolasku, tako i svaki vjernik već sada svojim ponašanjem može pobijediti zlo ili se barem uporno protiv njega boriti.

\section{Zaključak: (Re)kompozicija jednoga motiva u raznim kontekstima}

Ponovit ćemo kako promatrani tekstovi, nadređeni motivu/temi posta i molitve, pripadaju raznim književnim vrstama ili žanrovima: u COxf-u može se reći da je to prenje (dijalog dvaju suprotstavljenih likova, Isusa i đavla) na koje se nadovezuje propovijed, u CBč-u je to književni sastav različitih malih žanrova unutar okvira hagiografskoga (legendarnoga) teksta, dok je tekst u najmlađem CGrš-u moralnodidaktičnoga značaja. Iz propovjedno intoniranoga teksta u COxf-u razaznaje se namjera docere (poučavati). S druge se strane u prenju koje mu prethodi raspoznaju funkcije (pa tako s pomoću njih i autorova namjera, odnosno ono što se nastojalo postići) movere (poticati, ganuti publiku), pa čak i delectare (pružiti užitak, na 
neki način zabaviti) jer je riječ o Isusovoj pobjedi nad đavlom nakon uzbudljive prepirke. Veza propovijedi s apokrifom u COxf-u ocrtava tipično srednjovjekovno miješanje žanrova. Praktično (propovijed) je spojeno s estetskim (književni tekst, prenje), što je moglo djelovati kao novost, kao svojevrsno iznenađenje i ostvariti snažniji učinak. Stoga taj tekst u inačici kakva je zapisana u COxf-u valja čitati u odnosu na nešto što se privremeno može nazvati vernakularnom teologijom za širu publiku - to je zadatak koji tek predstoji našoj medievistici.

Postupcima dekompozicije (shvaćenoj u smislu kako ju rabi Mary Carruthers) i spajanjem poznatih motiva u nove sastave glagoljaši su se pokazali i kao svojevrsni autori koji su se predlošcima i izvorima (starijim predlošcima ili djelima na latinskom ili talijanskom jeziku) koristili prema potrebi, smisleno ih i namjerno kombinirajući u uvijek nove sastave, s raznim funkcijama i namjerama - pa i s raznim estetskim učinkom.

Post $i$ molitva mogu se promatrati kao motiv ili pak svojevrsno opće mjesto koje se ili obogaćuje ili krati te ilustrira raznim primjerima u raznim kontekstima, već prema potrebi (situaciji izvedbe/čitanja ${ }^{29}$ ) i namjeri autora, pisara ili kompilatora zbornika. Uklapanje motiva posta i molitve u cjelinu u CBč-u djeluje možda najmanje očekivano ili motivirano: uz tri iznimna sveca, tri iznimne osobe u povijesti crkve (oličenja dobrote/sućuti, mudrosti i umjerenosti te učenosti: Nikole, Benedikta i Grgura) kao početak uspona prema iznimnosti spominju se upravo post i molitva, kojima likovi ostvaruju svoju svetost i dolaze bliže k Bogu. Međutim, ali ne manje važno, oni svoju svetost ostvaruju na korist ljudima (čineći dobra djela, pišući redovničko pravilo i teološko-filozofska djela). Ti su primjeri ponešto drukčiji od onih što se navode u drugim dvama promatranim rukopisima: tamo su naime popisani likovi kojima su -osobno i konkretno - post i molitva pomogli; kako bi na taj način ili tim oruđem sebi donijeli pomoć, izbavljenje ili snagu. Međutim svi primjeri nadasve ističu korist i dobrobit kojom post i molitva oplemenjuju ljude.

U promatranim se glagoljskim zbornicima kombiniraju razni elementi preuzeti, naslijeđeni, upamćeni iz drugih izvora (možda ne nužno samo književnih/pisanih, možda i iz slika/fresaka ili liturgije?) i preslaguju se u novi mozaik. Jedan od takvih elemenata jest i post i molitva. Na taj se način razni glagoljski sastavi (doslovce: $s a$ stavi) mogu sagledavati i kao razloživi fenomeni, spomenici koji možda u sebi kriju i neke odzvuke izvora za koje mislimo da ih nismo imali ili da nisu glagoljašima bili dostupni. Znanstveno netočno (ali ne i neutemeljeno) može se kazati da su zapravo svi hrvatskoglagoljski nabožno-pripovjedni tekstovi poučni jer uvijek po-

\footnotetext{
${ }^{29}$ Primjerice čitanje apokrifnoga prenja i propovijedi uz nju na prvu nedjelju korizme, kako se spominje u naslovu COxf-a. S druge strane može se pretpostaviti čitanje legende o sv. Margariti na njezin blagdan, dok je poučni tekst u CGrš-u mogao biti čitan/kazivan u svakoj prilici.
} 
zivaju, poučavaju, upozoravaju i potiču na određeni način ponašanja. Stoga kadšto termin poučna proza i nije najsretniji; valja ipak priznati kako boljega zasad nema. Riječ je o neliturgijskim zbornicima različitoga štiva, u kojima prevladavaju vjerske i duhovne teme; kao takvi, zbornici su odraz i pastoralnoga nastojanja i odraz onodobnoga senzibiliteta, ali su i odraz čitateljske zajednice kojoj su bili namijenjeni. Autori (pisari, prevoditelji) u svojim tekstovima prerađuju, prilagođavaju, skraćuju ili obogaćuju tekstne predloške prema svojim mogućnostima i uvijek imajući pred očima pretpostavljenu publiku za određeni sastav ili čak za cijeli kodeks. Promatrani tekstovi pak dio su religiozne srednjovjekovne produkcije, pa se može govoriti dijelom i o specifičnoj vrsti pastorala i moralke kroz književne sastave.

Novo stvaranje ne odnosi se samo na nastajanje novih kompozicija i cjelina (pamćenjem/usvajanjem, dekompozicijom i ponovnim slaganjem) u smislu novih tekstova već i na duhovnu sferu. I primatelji su postajali na neki način novi, tj. obnovljeni - nakon čitanja/slušanja pobudbenih nabožnih tekstova nisu više bili isti, stari, grješni ljudi. ${ }^{30}$ Čitanje je samo po sebi bilo vrstom poticanja na ponašanje; ono što se čitalo bilo je egzemplarno pa se trebalo imitirati (ili pak izbjegavati) - u tom je smislu čitanje poticalo na $\gg$ izvedbu $\ll$, na $\gg$ realizaciju $\ll$, odnosno ostvarenje u stvarnom životu. ${ }^{31}$

Poruka je tih tekstova, usprkos njihovoj različitoj vrsnoj pripadnosti, u temelju zajednička: ako se ljudi pokaju i obrate, Zlo može biti sputano, zauzdano. Krist je pobijedio đavla, a svaki je vjernik pozvan stalno se boriti. Nagrada je obećana, ima nade, ima smirenja i ispunjenja. Post nije samo odricanje i kazna za prijestupe, nije samo čin svojevrsnoga žrtvovanja već je to moćno oruđe u savladavanju đavoljih napasti. U tome je, kako kaže jedan od pisara CGrš-a, moĉ ku ima post i molitva. A na kraju propovjednoga odsječka u COxf-u čak se izrijekom obećaje: zaisto i s(ve) to e(stb) post' cist' i m(o)l(it)vu čistu prinositi $b(\mathrm{og})$ u i podanie al'mužnoga s' lûbav'û $i$ s veru čistu i s'mêrenu. I ki ovo čine poidut'v rai. Dakle ufanje da će na kraju korizme svakomu svanuti uskrsno jutro puno milosti.

Svrha, skopós promatranih djela jest poticaj na molitvu i post te na činjenje dobrih djela uz obećanje svojevrsne duhovne (pa čak i fizičke) nagrade. Taj se poticaj iskazuje različitim književnim vrstama, uz veću ili manju pomoć estetskoga značenja i (skromnoga) ukrašavanja tekstova retoričkim figurama te spajanjem motiva posta i molitve (dakle nečega što bi se na prvi pogled svrstalo u pobudbene sadržaje) s

${ }^{30}$ Sperandum est, s motrišta autora koji se identificira s ovim svijetom, ali ga želi poboljšati i oduhoviti.

${ }^{31}$ Valja ipak biti oprezan u zaključcima; hagiografska djela, od $\gg$ Djela Pavla i Tekle « kao svojevrsne paradigme, davale su »običnim « vjernicima »not so much a model to imitate, something most of them never dreamt of doing, but rather a source of power to be tapped «. E. DUFFY, The Stripping of the Altars. Traditional Religion in England 1400 - 1580, New Haven - London, 1992., 175. 
pripovjednim oblicima kao što su prenje i legenda. I u ovdje analiziranim tekstovima zrcale se dvije važne karakteristike hrvatskoglagoljske proze: polifunkcionalnost, jer djela često ujedinjuju praktične (npr. pastoralne, moralne i poučne) funkcije $s$ estetskom, te otvorenost forme, jer se teme, motivi i slike često pojavljuju u uvijek novim kombinacijama i kontekstima. To je dio specifičnosti srednjovjekovne književnosti, koja - premda u nekim svojim odrednicama pomalo začudna i strana - i kod današnjega primatelja može pobuditi zanimanje. 


\title{
THE MOTIF OF FASTING AND PRAYER IN SELECTED CROATIAN GLAGOLITIC TEXTS OF THE $15^{\text {th }}$ AND $16^{\text {th }}$ CENTURY
}

\author{
Marija-Ana DÜRRIGL*
}

Summary: The Croatian Glagolitic medieval literature consisted mostly of religious texts (e.g. hagiographies, visions, debates/contrasts, Miracles of the Blessed Virgin, dialogue poems, miracle and morality plays). Some of them contain the motif of fasting and prayer as well as the benefits of self-renunciation, allowing men to become purer and better in their relationships towards both themselves (through fasting and self-renunciation) and other people (through good deeds and almsgiving), and to achieve a closer relationship with God (through prayer). The motif of fasting and prayer is frequently found in texts of various themes, forms, and genres over the centuries. It was present in European Christian literature from its beginnings to the early modern period, making it a long-standing motif. During the Middle Ages in Europe, that motif was most notably found in moral-didactic and pastoral texts, but also in narrative prose texts. Three Croatian Glagolitic manuscript codices were chosen for this research: Oxford Miscellany (15th c.), Berčić Miscellany (15th c.) and Grskković Miscellany (16th c.), as collections of texts exhibiting motifs of fasting, prayer and works of mercy. The recombination of the motif in different contexts (as a sermon in a debate, as a motif in a legend and as a starting point of a moral-didactic text) reflects the memory-based nature of medieval culture - that which is adopted as one's own, can be recombined rather freely. The three Glagolitic codices list Biblical figures and saints who found salvation from evil through fasting and prayer (e.g. Isaac, Lot, Susanna, Daniel, three young men in the fiery furnace, Saint Thecla, and Saint Margaret) and those in various ways blessed by God (e.g. Moses, Elijah, Joachim and Anne, the apostle Paul, Saint Nicholas, Saint Benedict). The list of characters is consistent to a large extent in all three manuscripts. The tone and style of the texts indicate that they were intended not only for a smaller religious community, but also for a wider audience. Two important features of Croatian Glagolitic prose are present in the analysed texts: polyfunctionality, because the texts combine practical (e.g. pastoral, moral and didactic) functions with the aesthetic function; and the openness of the form, because themes, motifs and images always appear in new combinations and contexts.

Keywords: fasting and prayer as a literary motif, Middle Ages, Early Modern age, Croatian Glagolitic literature, Oxford Miscellany, Berčić Miscellany, Gršković Miscellany.

* Marija-Ana Dürrigl, Ph. D., Old Church Slavonic Institute, Demetrova 11, 10000 Zagreb, Croatia, duerrigl@stin.hr 